\title{
H1 histone synthesis by implanting pig blastocysts
}

\author{
J. W. Brookbank*, R. D. Geisert $\uparrow$, J. D. Godkin $\ddagger$ and F. W. Bazer $\dagger$ \\ Departments of ${ }^{*}$ Microbiology and Cell Science, $\dagger$ Animal Science, \\ and $\ddagger$ Biochemistry and Molecular Biology, University of Florida, Gainesville, Florida 32611, U.S.A.
}

\begin{abstract}
Summary. Histones were isolated from pig conceptuses on Days 8-18 of pregnancy, Acid-urea polyacrylamide gel electrophoresis (PAGE) was performed on samples of total histone and on PCA-soluble histone fractions (primarily histone $\mathrm{H} 1$ ). Conceptuses were also incubated for $24 \mathrm{~h}$ in vitro in the presence of $\left[{ }^{3} \mathrm{H}\right] \mathrm{lysine}$, and the histones analysed by autofluorography after PAGE. A minimum of two $\mathrm{H} 1$ histone bands was resolved in stained gels by these techniques. The autofluorographs indicate that both $\mathrm{H} 1$ histones are synthesized throughout the developmental period analysed. No shift in $\mathrm{H} 1$ histone subtype, as encountered in sea urchin development, was observed. The results suggest that such a shift, if it occurs, may have been made before Day 8.
\end{abstract}

\section{Introduction}

H1 histones seem to be both tissue-specific proteins and regulator proteins, although direct evidence for regulatory activity is lacking. Studies of mammalian tissue culture cells reveal that various types of $\mathrm{H} 1$ histones characteristic of the species are expressed differentially depending on the specific genetic activity of the cells (Hohman, 1980). In embryonic systems, stage-specific changes in the synthesis of variants of $\mathrm{H} 1, \mathrm{H} 2 \mathrm{~A}$ and $\mathrm{H} 2 \mathrm{~B}$ histones of sea-urchin embryos have been observed by a number of investigators (Seale \& Aronson, 1973; Ruderman \& Gross, 1974; Cohen, Newrock \& Zweidler, 1975; Newrock, Cohen, Hendricks, Donnelley \& Weinberg, 1978; Harrison \& Wilt, 1982). The changes in histone synthesis during development reflect altered histone gene expression. The histone variants, especially the $\mathrm{H} 1$ variants, may in turn be related to changes in chromatin structure and changes in overall transcription activity which occur as development proceeds (Arceci \& Gross, 1981). There are indications that the shift in H1 histone type, from the earlier to the later variant, is not a result of the process of differentiation (Brookbank, 1978, 1980, 1982; Arceci \& Gross, 1980), since the shift in $\mathrm{H1}$ is made in dividing dissociated embryonic cells as well as in cleavage-arrested embryos which are synthesizing DNA.

Histone variants are represented by separate sets of tandemly repeated genes coding for early and late histones during sea-urchin development. The early histone mRNAs are transcribed from highly reiterated tandem repeat sequences (up to 1000 copies per genome). Later histones are coded by less highly reiterated sequences organized in clusters (Kunkel \& Weinberg, 1978; Kedes \& Maxson, 1981). The organization of histone genes in vertebrate species more closely resembles the late histone genes of sea urchins. Histone genes of human, mouse, chicken and toad cells are found as widely scattered gene clusters or in some instances as solitary genes, and are reiterated 40-80 times per genome (Kedes \& Maxson, 1981; Sierra et al., 1982).

Studies of histone synthesis in the preimplantation rabbit embryo indicate that overall histone synthesis is quantitatively co-ordinated with DNA synthesis (Matheson \& Schultz, 1980). The present report is concerned with the synthesis of histone during the early development (Days 8-18) 
of the pig blastocyst. Placentation in the pig occurs between Days 13 and 18 , and is accompanied by radical morphological changes in the blastocyst (Geisert, Brookbank, Roberts \& Bazer, 1982) and by the onset of oestrogen synthesis by the preimplantation blastocyst (Flint, Burton, Gadsby, Saunders \& Heap, 1979). Since a precedent exists in sea-urchin embryos for a change in type of $\mathrm{H} 1$ histone synthesized in advance of morphogenetic changes, pig blastocysts were examined to determine whether similar changes in histone synthesis occur between preimplantation and implanting embryos.

\section{Materials and Methods}

Conceptus material was obtained at hysterectomy (Murray, Bazer, Wallace \& Warnick, 1972). Conceptuses were flushed from the uterine horns using sterile saline (Zavy, Bazer, Thatcher \& Wilcox, 1980). Sexually mature crossbred gilts were used (Geisert et al., 1982). The first day of oestrous behaviour in the presence of sexually mature boars was designated Day 0 of pregnancy. Gilts were mated at 07:00 and 19:00 h on Day 0. Day 8 embryos were recovered from superovulated gilts which had received 12000 i.u. PMSG on Day 15 of the oestrous cycle (Guthrie, Henricks \& Handlin, 1974). The gilts were mated at the following oestrus. Spherical conceptuses were recovered on Day $8(n=40)$ and Day $11(n=11)$; filamentous conceptuses were recovered on Days $12(n=10), 16(n=11), 17(n=14)$ and $18(n=12)$.

Isolation of nuclei utilized a modified procedure of Bentinnen \& Comb (1971). Blastocysts were collected by centrifugation and rinsed in cold $0.85 \%(\mathrm{w} / \mathrm{v}) \mathrm{NaCl}$ to remove uterine cells and mucus. The final rinse was replaced with five volumes of Buffer A (0.045 $\mathrm{M}-\mathrm{NaCl}, 0.01 \mathrm{M}-\mathrm{EDTA}, 0.05 \mathrm{M}-$ $\mathrm{NaHSO}_{3}, 0.01 \mathrm{M}$-Tris, $\mathrm{pH} 7.4$ containing $20 \mu \mathrm{l}$ Triton $\mathrm{X}-100$ per $100 \mathrm{ml}$ ). Conceptuses were homogenized for $15 \mathrm{sec}$ using a micro-cup and Waring blender or by repeated passage through an 18-gauge needle fitted to a 5-ml syringe. Homogenates were inspected for nuclei and unbroken cells under phase-contrast optics, and then centrifuged at $800 \mathrm{~g}$ for $10 \mathrm{~min}$ to sediment nuclei. The pellet was suspended in a small volume $(<0.5 \mathrm{ml})$ of Buffer A layered over 2 volumes of $1 \mathrm{M}$-sucrose in Buffer $\mathrm{A}$, and centrifuged at $5000 \mathrm{~g}$ in a Fisher microcentrifuge for $10 \mathrm{~min}$. Since the samples were small, and since repeated centrifugations tended to result in losses of nuclei, the nuclei were

\section{PLATE 1}

Migration towards cathode, at bottom of gel; $13.5 \%$ acid-urea gel, $4 \%$ spacer gel in Fig. 1, Lanes 2-6.

Fig. 1. Lane 1 (silver stain): $20 \mu$ from Day-12 histone sample. Lane 2: $20 \mu$ of Day-17 total histone. Lanes 3 and $4: 15$ and $25 \mu \mathrm{l} 5 \%$ PCA-soluble histone. Lanes 5 and $6: 10$ and $15 \mu \mathrm{l} 5 \%$ PCA-insoluble histone. Bands numbered 1-4 represent histones $\mathrm{H} 1$ (one 'slow' component = $\mathrm{H} 1 \mathrm{~s}$, and three 'fast' components = H1f, resolved into three closely spaced bands), $\mathrm{H} 2$ (a and b), $\mathrm{H} 3$ and $\mathrm{H} 4$. Histones $\mathrm{H} 1$ and $\mathrm{H} 2$ are soluble in $5 \% \mathrm{PCA}$; histones $\mathrm{H} 3$ and $\mathrm{H} 4$ are insoluble in $5 \%$ PCA. Lanes $2-6$, Coomassie stain.

Fig. 2. Coomassie-stained gel. Lanes 1,2 and 3 are histone patterns from Day-17 blastocysts ( 5 , 10 and $20 \mu \mathrm{l} ; 6,12$ and $24 \times 10^{3}$ c.p.m. $\left[{ }^{3} \mathrm{H}\right]$ lysine). Lanes 4,5 , and 6 are patterns from Day-11 blastocysts $\left(10,20\right.$ and $40 \mu \mathrm{l} ; 3,6$, and $12 \times 10^{3}$ c.p.m. $)$.

Fig. 3. Autofluorographs of gel in Fig. 2. Lanes 1-3, Day-17 embryo histones. Lanes 4-6, Day11 embryo histones. Kodak XRP-5 X-ray film at $-70^{\circ} \mathrm{C}, 18$-day exposure. Bands numbered $1-$ 4 represent histones $\mathrm{H} 1 \mathrm{f}$ and $\mathrm{H} 1 \mathrm{~s}, \mathrm{H} 2$ (a and b), $\mathrm{H} 3$ and $\mathrm{H} 4$. Histone $\mathrm{H} 4$ is not represented in the autofluorograph. 
PLATE 1

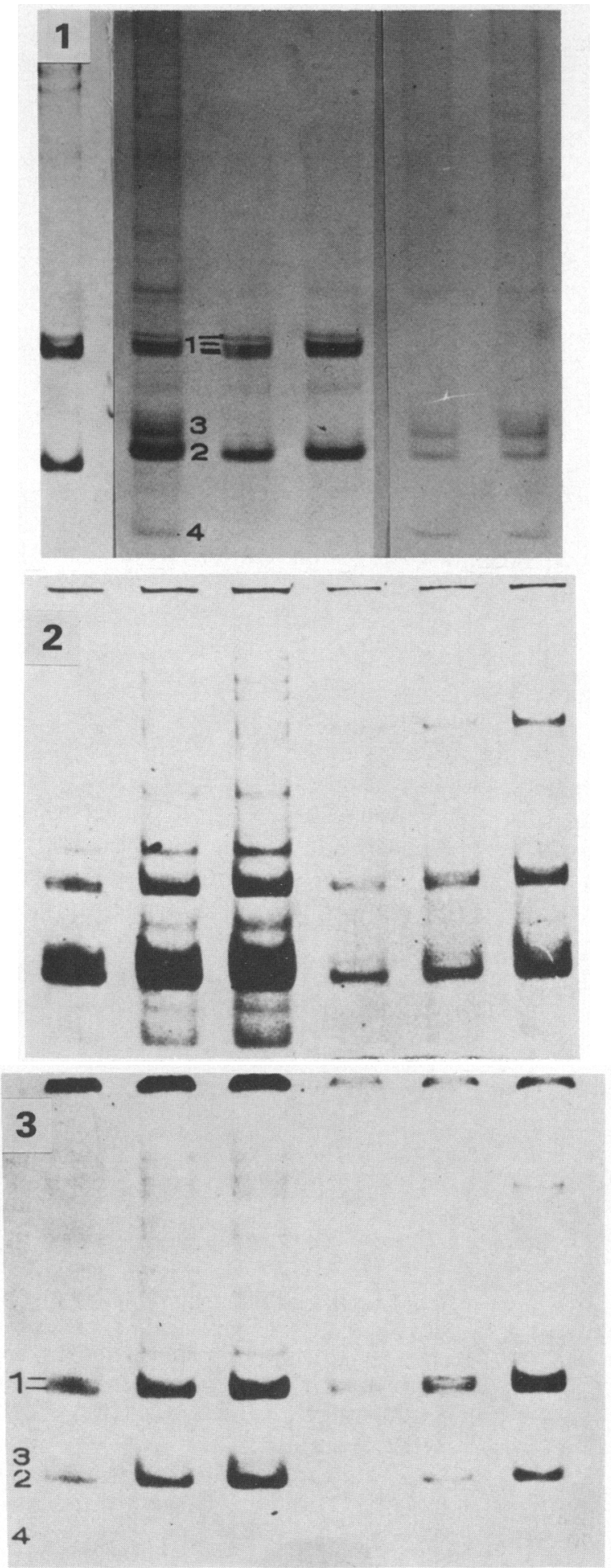

(Facing p. 298) 
PLATE 2

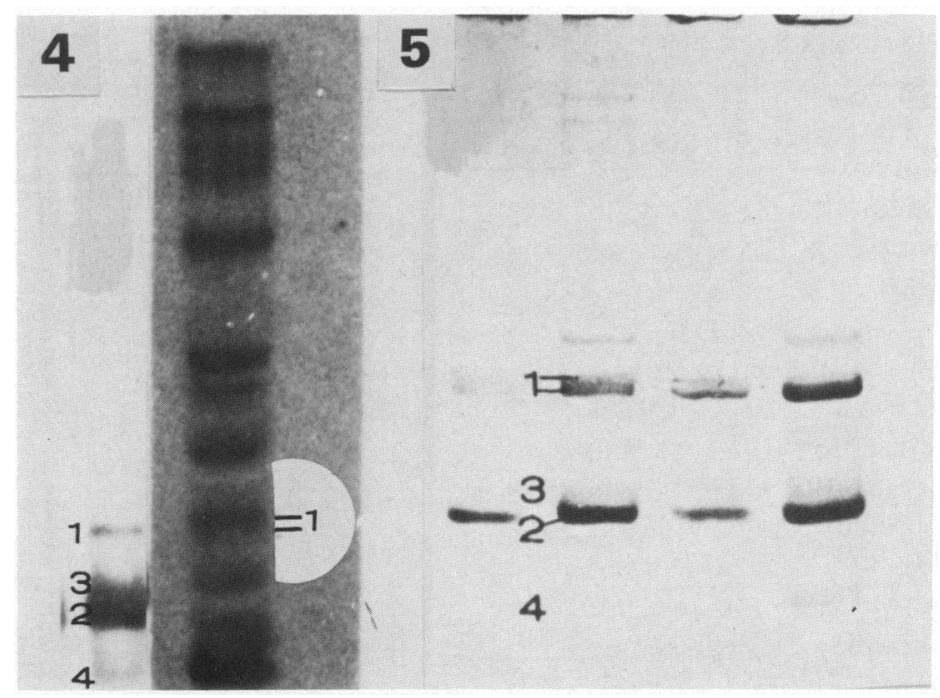

Migration towards cathode, at bottom; $13.5 \%$ acid-urea gels.

Fig. 4. Lane 1 = stained gel, Day- 8 embryo basic proteins plus calf thymus histone carrier. Position of $\mathrm{H} 1$ band marked on filter paper supporting gel before drying the gel for fluorography. Lane 2 = autofluorograph of basic proteins of 8-day embryos (gel pictured in Lane 1). Lines at ' 1 ' indicate position of $\mathrm{H} 1$ histone bands. HIf (towards the cathode) is distinct from Hls by virtue of lighter deposition of silver grains in Hlf. Total c.p.m. $=7 \times 10^{3} ; 4-$ month exposure in conditions as in Fig. 3.

Fig. 5. Stained gel, pig thymus histone. Lane $1: 2 \mu \mathrm{l}$ total unfractionated histone. Lane $2: 10 \mu \mathrm{l}$. Lane 3: $5 \mu l$. Lane 4: $15 \mu l$. 
recovered from beneath the sucrose, rinsed with deionized water and extracted without further purification for $2 \mathrm{~h}$ at $0^{\circ} \mathrm{C}$ in $0.5 \mathrm{~N}-\mathrm{H}_{2} \mathrm{SO}_{4}$. The acid extract was then centrifuged, and the supernatant containing histones precipitated overnight at $-20^{\circ} \mathrm{C}$ with 2.5 volumes of cold absolute ethanol. Histone precipitates were recovered by centrifugation, and dissolved in appropriate volumes of a mixture of $0.5 \%$ glacial acetic acid, $4 \mathrm{M}$-urea and $0.01 \mathrm{M}-2$-mercaptoethanol (Buffer B). Thymus tissue was obtained from newborn pigs and the histones extracted by the above procedure. Portions of the histone preparation from Day- 17 conceptuses were fractionated with $5 \%$ perchloric acid (PCA) (Johns, 1978) to help identify the stained bands. H1 histone can be precipitated from PCA solutions using 8 volumes of ethanol after making the solution $0.5 \mathrm{~N}$ with $\mathrm{H}_{2} \mathrm{SO}_{4}$. The precipitated histones are redissolved in Buffer B after twice rinsing the precipitate with cold $5 \%$ PCA. Due to the small volume of material, the Day 8 embryos were processed as whole homogenate without isolation of nuclei. Histones were labelled with $\left[{ }^{3} \mathrm{H}\right]$ lysine (below) during embryo culture, and the histone fraction was carried through with added unlabelled calf thymus histone.

Day 8 and some Day 11 and Day 17 blastocysts were separately cultured for $24 \mathrm{~h}$ under sterile conditions in Hank's medium at a temperature of $37^{\circ} \mathrm{C}$ in an atmosphere of $50 \% \mathrm{~N}_{2}, 45 \% \mathrm{O}_{2}, \mathrm{CO}_{2}$ (Godkin, Bazer, Lewis, Geisert \& Roberts, 1982) with $10 \mu \mathrm{Ci}\left[{ }^{3} \mathrm{H}\right] l y \operatorname{sine} / \mathrm{ml}$ (sp. act. $=75$ $\mathrm{Ci} / \mathrm{mmol}$ ). Conceptuses so treated continue synthesis of a number of extracellular and intracellular proteins (Godkin et al., 1982). The labelled embryonic material was processed as above, and the histones electrophoresed. Radioactivity in dried gels was detected using salicylate fluorography (Chamberlin, 1979).

Electrophoresis was performed on $13.5 \%(75: 1(\mathrm{v} / \mathrm{v})$ acrylamide : bis-acrylamide) polyacrylamide slab gels containing $5 \%$ acetic acid and $4 \mathrm{M}$-urea for $5 \mathrm{~h}$ at a constant voltage of $160-180 \mathrm{~V}$ with $5 \%$ acetic acid in the buffer wells. Best resolution was finally obtained when a spacer gel of $4 \%$ acrylamide ( $75: 1)$ and occupying $20 \%$ of the total gel volume was interposed between the bottom of the wells and the main gel. Slabs were stained with Coomassie Brilliant blue R, and, if necessary, silver nitrate (Merril, Goldman, Sedman \& Evert, 1980). Extraction procedures did not quantitatively remove $\mathrm{H} 3$ and $\mathrm{H} 4$ from the nuclei, especially at Days 11 and 17. The relative amounts of $\mathrm{H} 1$ histones in a given sample well can be visually compared following electrophoresis and staining; otherwise the gels are not quantitative.

\section{Results}

The patterns obtained from conceptuses between 12 and 17 days of gestation are shown in Pl. 1, Fig. 1. Plate 1, Fig. 1 also shows the pattern obtained with PCA-fractionated histone samples from 17-day conceptuses. Taken together, the figures show one slow $\mathrm{Hl}$ band (H1s) in all samples, preceded (towards the cathode) by a heavier band (H1f) which resolved into 3 components under ideal conditions. Other more slowly moving bands represented contamination of the sample by other basic proteins, possibly ribosomal proteins. Histone electrophoretic patterns of Day 16 and Day 18 conceptuses (not shown) were indistinguishable from those illustrated.

Plate 1, Figs 2 and 3 represent the results of autofluorography of $\left[{ }^{3} \mathrm{H}\right]$ lysine labelled histones from Day 11 and Day 17 conceptuses. The first bands to appear in the fluorographs were the $\mathrm{H} 1$ bands, a finding consistent with these proteins being very lysine rich. Both $\mathrm{H} 1$ histone bands, including the minor component with slower mobility, appeared to incorporate label at 11 and 17 days.

Plate 2, Fig. 4 shows the stained gel (pig thymus carrier histone) and autofluorograph obtained from Day 8 conceptuses. The $\mathrm{Hl}$ histones at Day 8 appear in the autofluorograph to be resolved into $\mathrm{H} 1 \mathrm{f}$ and $\mathrm{H} 1 \mathrm{~s}$ components, as found in samples from later embryos. The electrophoretic pattern derived from neonatal pig thymus is shown in Pl. 2, Fig. 5, The $\mathrm{H} 1$ patterns of neonatal and conceptus material are not readily distinguishable from one another. 


\section{Discussion}

Plate 1 (Figs 1 and 2) indicates that two major $\mathrm{H} 1$ histone components ( $\mathrm{H} 1 \mathrm{~s}$ and $\mathrm{H} 1 \mathrm{f}$ ) are present in all samples from Day 12 to Day 17. PCA solubility indicates that these bands are in fact $\mathrm{H} 1$ histone. Day 8 embryos reveal similar patterns through fluorography. The Day 8 fluorography pattern shows more intense label in $\mathrm{Hls}$ than in $\mathrm{Hlf}$, just the reverse of the later stages. It is possible that these embryos are just beginning synthesis of Hlf. Since Hlf is the major component of later developmental stages, it is possible that shift in $\mathrm{Hl}$ histone from $\mathrm{Hls}$ to include $\mathrm{Hlf}$ was made before Day 8, even though $\mathrm{H} 1 \mathrm{~s}$ seems to have incorporated more label during in-vitro embryo culture.

Under the present conditions (extraction from Buffer B solution with $5 \%$ PCA), it appears that histone $\mathrm{H} 2$ (a and/or b) is soluble in 5\% PCA along with $\mathrm{H} 1$ histone(s). The acid-urea system employed does not permit estimates of molecular size, e.g. for H1f and H1s. The autofluorographs in Pl. 1, Fig. 3 indicate that the $\mathrm{Hl}$ pattern visualized on stained gels reflects the pattern of $\mathrm{Hl}$ histones being synthesized over the experimental period between Days 11 and 17. The multiple H1 bands which are resolved in $\mathrm{Pl}$. 1, Fig. 1 might represent $\mathrm{H} 1$ variants, but more probably represent phosphorylated forms of $\mathrm{H} 1$ histones. Similar if not identical $\mathrm{H} 1$ histone patterns are found in the pig thymus histone sample (Pl. 2, Fig. 5).

In sea-urchin embryos a definite $\mathrm{Hl}$ shift is encountered at the late blastula stage, some hours before the beginning of gastrulation. Similar shifts have been described for other unrelated invertebrates (Mackay \& Newrock, 1982). The earlier H1 is typically conserved in later embryonic stages. If mammalian embryos follow a similar pattern, one might expect a shift in $\mathrm{H} 1$ subtype during development. In terms of time, sea-urchin embryos make the $\mathrm{H} 1$ shift at blastulation (about $15 \mathrm{~h}$ after fertilization, depending on temperature and species). Mammalian embryos are likely to be composed of only 1 or 2 cells at this time. From studies of ethanol-treated sea-urchin eggs, it is clear that time after fertilization and not developmental stage is the controlling factor in the $\mathrm{H} 1$ histone shift in sea-urchin embryos (Brookbank, 1982). In terms of time after fertilization, one might therefore expect the shift in mammalian embryos to occur during the first day of pregnancy.

Failure to observe a histone shift in pig blastocysts might be ascribed to any or all of the following. (1) The shift may have occurred before the first sampling day (Day 8). (2) The shift may be restricted to embryonic tissue only, and be masked by the predominance of extraembryonic tissues in the early conceptus. (3) A shift may have occurred between Days 8 and 18, but the new H1 variant was not resolved from the pre-existing $\mathrm{Hl}$ variant by the gel system used. A number of different acrylamide concentrations $(10-15 \%)$ and acrylamide : bis-acrylamide ratios $(37 \cdot 5:-150: 1)$ were tried, as were linear 10-15\% gradient gets, but resolution was not improved. (4) The shift may be scheduled to occur later than Day 18 ,

Alternative (1) seems most probable from all considerations, since H1f is apparently incorporating less radioactivity on Day 8 than on Days 11 or 17. Perhaps this is an indication that this histone has recently been switched on. A direct parallel with sea urchin development would presumably show an early $\mathrm{H} 1$ being conserved (and diluted out) while a later $\mathrm{H} 1$ is being synthesized and added to the nuclei at successive cell cycles. The present data are consistent with such an interpretation, but do not prove it.

Contribution number 4397 from the Florida Agricultural Experimental Station Journal Series. Supported by an NIH Biomedical Research Grant (to J.W.B.) from the Division of Sponsored Research, University of Florida.

\section{References}

Arceci, R.J. \& Gross, P.R. (1980) Histone gene expression: progeny of isolated blastomeres in culture make same change as in the embryo. Science, N.Y. 209, $607-609$. 
Arceci, R.J. \& Gross, P.R. (1981) Histone variants and chromatin structure during sea urchin development. Devl Biol. 80, 196-209.

Bentinnen, L.C. \& Comb, D.G. (1971) Early and late histones during sea urchin development. $J$. molec. Biol. 57, 355-358.

Brookbank, J.W. (1978) Histone synthesis by cleavage arrested sea urchin eggs. Cell Differentiation 7, 153158.

Brookbank, J.W. (1980) Effects of cordycepin and cell dissociation on the synthesis of $\mathrm{Hl}$ histone by sea urchin embryos. Cell Differentiation 9, 315-321.

Brookbank, J.W. (1982) Nucleic acid and histone synthesis by ethanol-treated cleavage arrested sea urchin embryos. Differentiation 23, 25-28.

Chamberlin, J.P. (1979) Fluorographic detection of radioactivity in polyacrylamide gels with the watersoluble fluor, sodium salicylate. Analyt. Biochem. 98, 132-135.

Cohen, L.H., Newrock, K.M. \& Zweidler, A. (1975) Stage specific switches in histone synthesis during embryogenesis of the sea urchin. Science, N.Y. 190, 984 997.

Flint, A.P.F., Burton, R.D., Gadsby, J.E., Sauders, P.T.K. \& Heap, R.B. (1979) Blastocyst oestrogen synthesis and maternal recognition of pregnancy. In Maternal Recognition of Pregnancy (Ciba Fdn Symp. No. 64), pp. 209-238. Ed. J. Whelan. Excerpta Medica, Amsterdam.

Geisert, R.D., Brookbank, J.W., Roberts, R.M. \& Bazer, F.W. (1982) Establishment of pregnancy in the pig. II. Cellular remodeling of the porcine blastocyst during elongation on day 12 of pregnancy. Biol. Reprod. 27, 941-955.

Godkin, J.D., Bazer, F.W., Lewis, G.S., Geisert, R.D. \& Roberts, R.M. (1982) Synthesis and release of polypeptides by pig conceptuses during the period of blastocyst elongation and attachment. Biol. Reprod. 27, 977-987

Guthrie, H.D., Henricks, D.M. \& Handlin, D.L. (1974) Plasma hormone levels and fertility in pigs induced to superovulate with PMSG. J. Reprod. Fert. 41, 361370.

Harrison, M.H. \& Wilt, F.H. (1982) The program of H1 histone synthesis in $S$. purpuratus embryos and the control of its timing. J. exp. Zool. 223, 245-256.
Hohman, P. (1980) Species- and cell-specific expression of $\mathrm{H} 1$ histones in tissue culture cells. Archs Biochem. Biophys. 205, 198-209.

Johns, E.W. (1978) The isolation and purification of histones. In Methods in Cell Biology, Vol. XVI, pp. 183-203. Ed. D. Prescott. Academic Press, New York.

Kedes, L.H. \& Maxson, R. (1981) Histone gene organization: paradigm lost. Nature, Lond. 294, 11-12.

Kunkel, N.S. \& Weinberg, E.S. (1978) Histone gene transcripts in the cleavage and mesenchyme blastula embryo of the sea-urchin. Cell 14, 313-326.

Mackay, S. \& Newrock, K.M. (1982) Histone subtypes and switches in synthesis of histone subtypes during Ilyanassa development. Devl Biol. 93, 430-437.

Matheson, R.C. \& Schultz, G.A. (1980) Histone synthesis in preimplantation rabbit embryos. J. exp. Zool. 213, 337-349.

Merril, C.R., Goldman, D., Sedman, S.A. \& Ebert, M.H. (1980) Ultrasensitive stain for proteins in polyacrylamide gels shows regional variation in cerebrospinal fluids. Science, N.Y. 211, 1437-1438.

Murray, F.A., Bazer, F.W., Wallace, H.D. \& Warnick, A.C. (1972) Quantitative and qualitative variation in the secretion of protein by the porcine uterus during the estrous cycle. Biol. Reprod. 7, 314-320.

Newrock, K.M., Cohen, L.H., Hendricks, M.B., Donnelley, R.J. \& Weinberg, E.S. (1978) Stage-specific mRNAs coding for sybtypes of H2A and H2B histones in the sea urchin embryo. Cell 14, 327-336.

Ruderman, J.V. \& Gross, P.R. (1974) Histones and histone synthesis in sea urchin development. Devl Biol. 36, 296-298.

Seale, R.L. \& Aronson, A.I. (1973) Chromatin-associated proteins of the developing sea urchin embryo. II. Acid soluble proteins. J. molec. Biol. 75, 647-658.

Sierra, F., Lichtler, A., Marashi, F., Rickles, R., Van Dyke, T., Clark, S., Wells, J., Stein, G. \& Stein, J. (1982) Organization of human histone genes. Proc. natn. Acad. Sci. U.S.A. 79, 1795-1799.

Zavy, M.T., Bazer, F.W., Thatcher, W.W. \& Wilcox, C.J. (1980) A study of prostaglandin $F_{2} \alpha$ as the luteolysin in swine. V. Comparison of prostaglandin F, progestins, estrone and estradiol in uterine flushings from pregnant and nonpregnant gilts. Prostaglandins 20, $837-851$. 